\title{
Towards the democratization of the future: The struggle for social recognition and economic success of a West African association of working children and youth
}

2019, Vol. 26(2) 139-152

(c) The Author(s) 2019

Article reuse guidelines: sagepub.com/journals-permissions DOI: 10.1 | 777/0907568219828807 journals.sagepub.com/home/chd

@SAGE

\section{Sarah Fuchs}

University of Konstanz, Germany

\begin{abstract}
The African Movement of Working Children and Youth aims to empower and support young people, who otherwise would be excluded from educational and socioeconomic chances, to 'prepare their future'. In so doing, they re-interpret and re-combine transnational and local frames of reference in order to legitimize and materialize their ideas. I conceptualize this commitment as promoting a democratization of the future because they broaden the meaning of the (good) future as well as the means of access to it.
\end{abstract}

\section{Keywords}

Childhood and youth, children's rights, cultural translation, Senegal, social activism

The African Movement of Working Children and Youth (AMWCY) aims to empower and support young people, who otherwise would be excluded from educational and socioeconomic chances, to 'prepare their future'. In so doing, they re-interpret and re-combine transnational and local frames of reference in order to legitimize and materialize their ideas. I conceptualize this commitment as promoting a democratization of the future because they broaden the meaning of the (good) future as well as the means of access to it. [Childhood and youth, children's rights, social activism, cultural translation, Senegal]

\section{Introduction}

[...] I had very good marks but I had to drop out of school, because my mother was pregnant and she needed me to help her in the household [...]. When I dropped out of school, everybody

\section{Corresponding author:}

Sarah Fuchs, Division of Social and Cultural Anthropology, Department of History and Sociology, University of Konstanz, D-78457 Konstanz, Germany.

Email: sarah.fuchs@uni-konstanz.de 
said to me, now you do not have any future any more. But since I joined the AMWCY, I've known that this is not true. [...]. (Fatou ${ }^{1}$ May 7, 2012, my translation)

These were the words, translated from French, of Fatou, an 11-year-old girl living in the outskirts of Dakar, when interviewed in the context of a large pan-African conference on 'child protection systems' held in Dakar in May 2012. Her statement was quite telling about the African Movement of Working Children and Youth (AMWCY). As most of the members of the AMWCY, Fatou had to leave behind formal school education for socioeconomic reasons. In their association, the WCY - an acronym the children and youth use when they refer to themselves as members of the AMWCY - are enabled to enlarge their competences by studying French and learning couture, and to engage in children's rights activism in order to improve the living conditions of themselves and of other children in 'difficult situations'.

Working children's movements have their origin in Latin America in the late 1970s, and took root in Africa and Asia since the early 1990s. The AMWCY was founded in 1994 in Ivory Coast, and is currently represented in 27 African countries. It has turned into a relatively well-established movement that is mainly funded by Enda Third World, a transnationally operating organization of Senegalese origin, and occasionally by other influential non-governmental organizations (NGOs) like Save the Children or Plan International. Overall, a slight majority of the organization's members are female, whereas in Senegal, where my analysis refers to, the number of female members greatly exceeds their male peers. The groundwork of the AMWCY is 12 rights that have been developed by the original members at the establishment of the organization. These rights include the right to learn to read and write, to express oneself, to be taught a trade, to play and leisure, to health care, to be listened to, to rest when sick, to work in safety, to be respected and to have dignity, to stay in the village, to light and limited work and to equitable justice (AMWCY, 2016).

By overcoming the limited life perspectives economically disadvantaged youth have in Senegal, as I will argue in this article, the activities of the AMWCY can be subsumed under a struggle for their 'right to a future'. I will show how WCY therefore translate transnational as well as local discourses and build on moral and social resources. It will become evident that these implications challenge the dominant worldviews of both the milieu they originate from and of transnational child protection agencies. The impact AMWCY membership has on the members' lives is the outcome of a complex interplay between material and ideational assets, whereby the organizational structure allows the girls to occupy leader positions and other roles they wouldn't be able to undertake in the 'real' world. My conclusion is that the WCY strive to democratize both the meaning of as well as the access to 'a good future', which it assumes, paradoxically, by relativizing hegemonic children's rights policies.

My article contributes to a growing body of research that critically engages with 'children's rights' understood as a normative framework with universal meaning (Ennew, 2000; Morrow, 2010; Nieuwenhuys, 2001). Several studies (Crivello, 2011; Jacquemin, 2006; Montgomery, 2008; Woodhead, 1998) have shown that the formal language of rights cannot get hold of the complex life realities of working children and that children 'remain factually dependent on the benevolence of adults' (Liebel, 2012: 238). In 
contrast, social activism of working children has so far received only limited academic attention (Hahn and Holzscheiter, 2013; Liebel, 2012; Nieuwenhuys, 2009), and further ethnographic research is needed in order to develop a grassroots-based understanding of 'children's rights'.

\section{Methodology}

My analysis draws on the ethnographic material that I gathered during approximately 15 months of fieldwork in 2012 and 2013 for my $\mathrm{PhD}$ research on controversies on begging Qur'anic students (talibé) in Senegal. Following a multiperspective approach, I came into contact with the AMWCY group of the Dakar region, which is also engaged in improving the living conditions of the talibé. Given this only 'indirect' research interest, my analysis cannot take into account further ethnographic material of organizations concerned with working children or of other sections of the AMWCY out of Senegal. Also, my study is temporally bounded to a period of approximately 2 years and thus does not follow up the larger biographical impacts the adherence of the movement has to its members. Yet, it zooms in on the temporally, spatially, and socially localized practices of a distinct section of the AMWCY and links it to the overall discourses of the organization as well as of transnational children's rights agencies. Although the discourses of the AMWCY are embedded in a field of complex, and sometimes contested, practices of individuals, the WCY also have developed a kind of 'collective will' through their sessions of joined reflection and shared life experiences (Liebel, 2012: 226).

I was introduced to the young AMWCY members by the adult coordinators of the organization who I have interviewed before. In contrast to most transnational NGOs, the role of these adult coordinators and tutors is not meant to offer advocacy to the children, but rather background support and consultancy (Hahn and Holzscheiter, 2013: 510). As the girls were very open towards my acquaintance and my participation at their activities, I could easily get into deeper contact with a group of about four or five of them and occasionally met the other members of the groupe de base, the smallest unit of the AMWCY consisting of 5-6 girls living in the same neighbourhood, and the members of the entire Dakar section (20-30 girls). I conducted participant observation during their meetings to plan forthcoming activities, for example, International Workers' Day on 1 May; the 'Week of the African Child' or the national 'Talibé's Day', as well as during these activities themselves. Besides that, I also spent a lot of informal time with the girls. They considered me rather as a young adult friend ${ }^{2}$ than as a 'researcher' and were curious and welcoming towards me, most probably also linking my company with opportunities for self-enhancement and material benefits.

The close social contact with the girls proved to be an ambivalent asset for my research because, on the one hand, it allowed me to obtain deep and multidimensional insights in some of the girls' lifeworlds and, on the other hand, I had to respect and take into account their personal relations in order not to offend them. That way I was not fully free in choosing and developing my contacts within the AMWCY group. In addition, I occupied an undefined and sometimes uneasy position between the girls and the adult tutors and coordination staff who were present at any internal or official meeting. 
My main contact was Awa, a 19-year-old girl who had grown up in her paternal aunts' house in a Dakarois suburb. She had to drop out of school shortly after integrating the collège because her family couldn't afford the school fees any longer. After 1 year or so staying at home and keeping the house for her aunt, she joined the AMWCY section. There were discrete, but remarkable tensions between Awa and Ndiaye - as déléguée nationale ('national delegate') actually the girl I first got into contact with - who were both competing for leading positions within the group. Consequently, my relation with Ndiaye was cooling down when Awa began to regularly invite me in her house. Awa, however, was very good friends with Fatou, the girl I cited above. Fatou, 11years old, was one of the youngest AMWCY members. Because of her young age and her winsome personality - she was strikingly bright and kind - Fatou was elected as new déléguée nationale during my research stay. The other members I got to know relatively well mostly had quite similar backgrounds. While some of them worked in their family households besides their AMWCY activities, others were employed as domestics or gained some money with hair plaiting. Some of the older girls had boyfriends and talked about the wedding projects which they had but wanted to postpone it in order to prepare their future first.

\section{From victim to actor: Redefining the societal position of 'poor youth'}

As indicated in their publication with the same name, the AMWCY wants to transform victims into actors (Enda Tiers-Monde Jeunesse Action, 2008). This aim demands a redefinition of youth, especially poor and female youth, from both a local and a transnational point of view. From a local perspective, minors are mainly supposed to conform to the expectations of their family due to gerontocratic and patriarchal patterns. In Senegalese popular milieu, households are traditionally composed of the extended family ('concessions'), and the younger members are used to grant symbolical and practical privileges and gestures of subordination towards their elders. After their marriage, young women usually move directly from their father's household to that of their husband's family and only change, at least from a normative stance, the person from whom they socially and economically depend. While traditional female life prospects narrow the scope of argumentation for girls who want to continue their education, the economic scarcity of the WCY's social environment can play to their favour and open new opportunities for negotiation as a husband's income often is insufficient to sustain the entire family.

The transnational mainstream approach to 'development', by contrast, indeed aims to empower children and adolescents, especially girls, but mostly through approaches built upon Western concepts of personhood and society. Children are supposed to grow up in their nuclear biologic families and to receive formal schooling before engaging in any economic activities. In consequence, children who do not correspond to these forms of socialization are victimized as being 'at risk' or suspected to pose a risk to society itself (Conolly and Ennew, 1996).

In this twofold restrictive climate, the young AMWCY activists need to create and reinterpret social categories and 'frames of references' (Loimeier et al., 2005) in order to establish themselves as legitimate social and economic actors. In so doing, they 
draw both on local and transnational logics of thinking and recombine these ideas into new life concepts. For example, the WCY do not question conventional classifications like being 'young' or being 'female' but enlarge their intra-categorical and intercategorical flexibility (McCall, 2005). They claim recognition for being a 'child' and, at the same time, a 'worker' or being 'young' and nevertheless being listened to. They do not accept lacking 'the right to speak up' due to their age, however, accord great value to the voice of the elders. Not doubting if they will marry and have children, they postpone both in order to 'prepare' their future first. Having, mostly for economic reasons, abandoned their school careers, they still hold on some elements of formal education, mainly French literacy.

By adopting the transnational language of rights, they also seize the power of the global human rights discourse (Merry, 2006a: 42). When doing so, they, however, reverse international child protection policies' understanding of children's right to be free from any kind of labour by the claim to have their right to work recognized (Liebel, 2012: 225), albeit in a limited, non-exploitative manner. Although the growing interest in children's participation brought forward by the UN Convention on the Rights of the Child (United Nations, 1989) also provided new references for socioeconomically disadvantaged youth to be recognized as activists and International Labor Organization (ILO) Convention 182 (ILO, 1999) against the 'worst forms of child labour' has been seen to reflect increasing tolerance towards the potential sociocultural and economic significance (the non-worst forms of) children's work can have (Myers, 1999; Nieuwenhuys, 1996), the most recent ILO Global Conference on the Sustained Eradication of Child Labour in Argentina in November 2017 once again showed that working children's organizations are seldom welcome actors on the stage of international child policies. To have their voices heard and bring to light other needs and visions compared with the master narrative of 'eradicating child labour', a month earlier a parallel conference in Bolivia was organized with the support of some prominent practitioners and academics (Van Daalen and Mabillard, 2017).

The WCY, however, not only interpret and prioritize 'children's rights' differently than UN bodies do, but understand them in a dialectic relation to several 'duties' they have to respect, such as the duty to listen to the elders and not to prostitute themselves (Bada et al., 1999), borrowing in this regard from the African Charter on the Rights and Welfare of the Child (Organisation of African Unity [OAU], 1990). While the WCY understand themselves as part of, and not as opponents of international children's rights activism, they seize these 'rights' and adapt them to fit their concrete life experiences (Liebel, 2012: 238).

\section{Sociocultural and physical proximity as a resource}

To promote and to realize their claims and visions, the WCY need educational, social, economic and moral resources. However, in order to re-negotiate their marginal position, they reinterpret and re-prioritize these resources by 'chang[ing] the terms of recognition' (Appadurai, 2013: 289-290). Especially social resources are crucial for them because of their low socioeconomic background, which causes not only a lack of money but also a lack of powerful strategic relationships. Following a snowball approach to spread their 
messages, awareness raising is one of their flagship methods. This can take place both in planned sensitization sessions and in more spontaneous ways, for example, when they encounter a child or adolescent who is in trouble. One day Awa told me she had met a sick talibé who had been begging in the street for fear of punishment when not bringing enough money. She then accompanied the boy to his Quranic school in order to sensitize his master. In so doing, she did not criminalize the master nor question the Quranic education with its tradition of seeking alms in general, but neither did she accept the fact that the talibé was denied his right to rest when sick.

Furthermore, the WCY practice the so-called 'porte à porte' ('door to door') method and go from house to house in order to promote certain concerns. As a visit in Senegal is generally appreciated as gesture of respect and courtesy, they make use of their local knowledge and physical proximity to their target groups. In addition, they take advantage of the low material and financial efforts that interpersonal forms of awareness raising require and, even more importantly, of the consensus orientation inherent in this form of communication. Also, so-called set setal activities are part of their repertoire of methods, which means to use cleansing a neighbourhood as a message and communication tool. Set setal, the Wolof expression for 'to be clean and make clean', is a movement that came up in the late 1980s to protest against the misgovernment of the ruling classes. The activists came from a socioeconomically disadvantaged urban milieu and wanted to distance themselves from the rather elite student protests. Through public cleansing sessions of neighbourhoods, these young activists not only attracted public attention but also expressed their claim for spatial, economic, and social participation in the urban scape (Benga, 2001). As a counterdraft to national, hegemonic programmes, their activities had a direct impact on their immediate environment (Diouf, 1996, 2005). Set setal thus perfectly conforms to AMWCY paradigms and convictions. Cleaning a neighbourhood means showing commitment to a community as well as striving for improvement through 'honest', low-cost and shared work.

\section{Morality as investment for the future}

The idea of 'honest work' and their concern about how they gain their money constitutes a core element of the moral groundwork of the AMWCY and hints directly to the strong future orientation of the movement. The WCY refuse any work they consider to be morally objectionable as well as to be stuck in temporary, unqualified employment. This is why they mainly engage in tailoring training. Tailoring is considered to be one of the most sustainable economies in Senegal, where a new boubou (traditional Senegalese dress) is for many the minimum they afford for any kind of festivities. But tailoring is also a handcraft, thus undoubtedly 'honest' and does not require an excessively expensive equipment. It is, hence, even more than a pragmatic choice because it symbolically reflects the principles they stand for: to engage in 'stable' and 'honest' work which does not overstrain their educational nor financial capacities.

A solid moral foundation is of high significance to the AMWCY activists as it is often not easy for them to justify their activities towards a critical and sometimes even adversarial public. Trying to change people's mind while being underage, formally uneducated and poor means reversing the 'standard flows of expert knowledge' (Appadurai, 2001: 36) 
and thus a constant struggle for authority and legitimacy. As AMWCY members describe in one of their publications, their unusual position causes multiple allegations and claims from local as well as transnational actors. While in some villages, parents and elders suspected them of revolting against traditional social patterns due to their discourse of "children's rights', transnational child protection agencies presumed them to fight for, and not against, child labour (Enda Tiers-Monde Jeunesse Action, 2008: 64-65).

The moral groundwork of the AMWCY thus combines emancipatory with conservative elements. The WCY do not question the moral master frame of the society they live in, which is mainly based on religious as well as on 'cultural' references, but they reinterpret this frame in order to increase their agency within it. One of the topics they engage in is, for example, the fight against early marriages. They participate in sensitization sessions for 'communities at risk' and argue, mainly with medical arguments, against too early marriages. At the same time, they exhort the girls not to engage in premarital sexual relationships because this 'would not be good for their families'.

But their processes of appropriation do not only concern ideational but also material dimensions of transnational discourses. Most of the groupes de base, for example, open shared bank accounts. By pooling together their savings, they are able to reach the minimum amount of money required to open a bank account while keeping their respective parts meticulously separate. They hold a savings book, managed by the group's leader, in order to document each account movement. By this process they not only combine collectivist and individualist elements in a clever manner but also manage to get access to a major symbolic and practical tool of participation in modern societies. But rather than using the bank account as a means to have permanent access to consumption, they use it to save money from daily consumption. They appropriate a traditional monopoly of (working) adults and claim their equal right to manage the fruits of their work in a safe, official, and beneficial way. At the same time, saving money not only has pragmatic advantages, but has an ideational dimension as 'moral core of a politics of patience' (Appadurai, 2001: 33).

The transnationally acknowledged value of 'independence' is thus deeply interwoven in the groundwork of the AMWCY, but in a sense that stresses its social embeddedness. The WCY strive to take over elements which they formerly experienced as structurally given - for example, the hard working conditions of young domestics - into the sphere of their agency. That way they diminish their dependency on and the effects of social and economic barriers. 'Owning' skills rather than elusive material property is thus part of their reinterpretation of resources. Instead of being a 'bare body' (referring to Agamben, 1998) and an easily exchangeable employee, the WCY enhance their subjectivity by incorporating skills and making them an inseparable part of themselves. At the same time, however, they heighten their dependence towards social networks they cultivate and benefit from and towards (re-interpreted) moral and cultural values they identify with, thus actively create new structural patterns (Brettell, 2002: 440-441).

\section{Ambivalent stances towards youth mobility}

The (switching) stance towards child and youth mobility illustrates best, how the AMWCY combines conservative and emancipatory elements, how their discourses are 
embedded in, and at the same time differ from, powerful transnational discourses, but also how the official policy guidelines of the organization do not always fully correspond to the perspectives of the individual members.

The 'right to stay in the village' is one of the 12 rights the AMWCY accord to children and adolescents. Its very formulation combines conservative elements, expressed by the terms 'to stay' and 'the village', with the emancipatory notion of 'having rights'. The claim that the rural youth must not be obliged to move to urban centres in order to have a 'good future' actually mirrors the core paradigm of the AMWCY: poor youth should redefine the 'packaging' for a fortunate life, using the resources they have access to in a creative manner instead of blindly following master tales of ways to success. Ruralurban mobility of minors in the search for work and better life chances, however, is socioeconomically and socioculturally deeply embedded in West Africa (Hashim and Thorsen, 2011). For many young, (temporal) urban migration is not only necessary to gain money for their school enrolment or wedding project, but it is also a kind of social 'rite de passage' (Van Gennep, 2000 [1909]) to achieve the status of a 'young adult' (Thorsen, 2007).

In line with the transnational master politics of its funding partners, the AMWCY was hostile towards rural-urban youth migration until the early 2000s. It warned of the risky urban environment and promoted economic projects that could be realized in the villages and make a 'precocious exodus' unnecessary. Interestingly, it also picked up the globally rising issue of 'child trafficking', albeit with a critical stance towards its criminalizing and repressive thrust (Enda Tiers-Monde Jeunesse Action, 2003: 69; Enda Tiers-Monde Jeunesse Action, 2000: 14). In recent years, however, influenced by the paradigmatic shifts of their transnational partners, the AMWCY showed a more liberal attitude towards youth migration, promoting to 'accompany the children in their mobility' instead of categorically refusing it (Enda et al., 2011). Yet, they still vehemently object to any kind of mobility which is not carefully prepared, namely leaving without any reliable contacts at the destination point and without a minimum of monetary savings. But by warning only of the practical risks and dangers that could possibly arise outside the social milieu of origin, they renounce any ideological or normative argumentation against child and youth mobility.

However, these formal policies do not in either case reflect the personal attitudes of the individual AMWCY members, whose respective reference points for their affective and rational stance towards child mobility are mostly rooted in their personal background. Fatou, for example, who was very close with her family, remarked that she cannot 'understand children who leave their families behind', while Awa, who, at that time, did not feel justly treated by her foster mother and sister, said to me ' $[\ldots]$ you know, in Senegal, it is a bit difficult if you don't stay with your mother [...]'.

The official AMWCY's stance towards geographical mobility thus mirrors its attitude towards social mobility: it advocates the 'secure way' based on skills and social networks but also values opportunities viable in the original milieus in order to remake conventional narratives of success which pre-exclude 'the village'. Albeit the WCY are not resigned to their weak socioeconomic position, they nevertheless keep in mind their vulnerability due to it, knowing that they cannot afford any risky endeavours. 


\section{Renegotiating social positions on a virtual and actual level}

Taking a closer look at the inter- and intra-organizational order of the AMWCY reveals the complex social and personal implications for its members. As a transnational horizontally and vertically connected grassroots organization, the AMWCY stands for new 'globally circulating visions of emancipation' (Appadurai, 2001: 24) and epitomize what Appadurai (2001) calls 'deep democracy' and 'globalization from below'. With these concepts, he shows how disenfranchised urban groups make use of creative strategies to render societal inequalities visible and how this opens new democratic spaces.

Membership in the AMWCY can raise young people from society's margins into the position of societal intermediaries. Their intermediate position, however, clearly differs from that of the 'development broker' analysed by Bierschenk et al. (2002) (cf. Merry, 2006b; Rossi, 2006) as a new social category in Africa, generated by the increasing transnational flow of development projects that need to be vernacularized. Even if the WCY aim to 'reconcile' the 'informal' parts of society with the 'institutional system' (Enda Tiers-Monde Jeunesse Action, 2008: 72) and thereby translate local grievances into a transnationally resonant vocabulary (e.g. 'the right to work') and transnational concerns into locally accepted frames (e.g. the fight against precocious marriages), they are agents of their own interests and convictions. Cooperation with the AMWCY can, nevertheless, be advantageous for transnational organizations. It helps them to package their own activities in a 'cultural resonant' (Snow, 2004) and transnationally recognized way, given that child 'participation' is a core principle of the UN Convention on the Rights of the Child (1989). Hence, the WCY do not upgrade their societal position through conventional tools of success (e.g. formal diploma) but by converting their allegedly disadvantageous origin into a resource. Nevertheless, this 'intermediate level' remains predominantly symbolic. It leads to some material or other benefits but hardly to a significant and stable increase in social prestige. The 'upgrade' can even be regarded as ambivalent because although it indeed strengthens the societal participation of the WCY, it also congeals them as 'working children and youth', which carries stigmatizing implications.

In addition, the internal federal and democratic structure of the AMWCY offers a broad spectrum of positions beyond the ordinary member status. In addition to leadership positions in the respective organizational levels (departmental and national), there are other special positions the members can be elected for, for example, to be treasurer or responsible for 'communication issues'. These positions represent not only an upgrade within the AMWCY community, comprising the participation in a range of seminars and travel opportunities with benefits like allowances but also, and maybe even more importantly, an increase in self-enhancement. The designations of such positions, like being 'in charge of ...' ('chargé(e) de ...') or 'national deputy' ('délégué(e) national(e)'), borrow the language of formal careers. When I added my main AMWCY informant Awa to my Skype contacts, I noticed that in the message line below her name appeared 'sarge de la communication du departement de Pikine [sic]'. The orthographic mistake $^{4}$ she made in her proudly advertised position ironically manifested the gap between her low educational background and the promising title of being in charge 
['chargée'] of communication'. Even if these AMWCY members do indeed have some 'real' functions within the sphere of influence of the AMWCY, from a large scale point of view they seem to bear these titles and signifiers of success on a mere virtual level. That way, however, they appropriate titles and honours they would otherwise hardly be able to occupy. Besides the very practical implications the AMWCY membership is meant to have (and does have), it also opens up a more hidden and symbolical space to the young activists. In this space, the members can escape the strict pragmatism and realism they usually (have to) pursue. At the same time, these responsibilities within the organization do have positive effects on their skills and self-perception through a complex interplay of imaginary and practical forms of appropriation.

\section{The AMWCY and the future: Some theoretical reflections}

'To prepare the future' build the very core of the WCY's raison d'etre to which all of their activities and discourses can be subsumed. The meaning this guiding principle has to them is best defined as a negation of 'muddling through', 'se débrouiller' in French. In Senegal, 'se débrouiller', or being a 'débrouillard', is a common buzzword for the life style and attitude of the many who have no fixed income or marketable skills and thus depend on irregular, often exploitative, occasional jobs and helpful others. The authors that so far have done research on the notion 'se débrouiller' differ in their interpretation from locating it close to trickery and criminalization (e.g. Bayart et al., 1999) to stressing its virtues of creativeness, flexibility, and adaptability (e.g. Waage, 2006). In Senegal, the social perception of 'se débrouiller' is similarly twofold. It can be considered as the 'skill of the poor' as it stigmatizes a person as socioeconomically disadvantaged, but within this categorization it is rather positively connoted as the capability to make the best out of the situation.

Even if one agrees with Vigh (2009) that 'se débrouiller' is oriented towards the near future and even holds possibilities for the more distant future, the crucial point why the AMWCY is aversive towards such a life style is the lack of potential for projectable personal development. While 'se débrouiller' stands for unpredictably moving back and forth between periods of being less or better off, the WCY prefer to have a concrete life project that they will achieve little by little. In addition, the life style of 'se débrouiller' is a very individualistic one: someone who 'muddles through' acts solely for his or her survival while highly depending on others as well on external circumstances. Nevertheless, the WCY distinguish between 'se débrouiller' as a short term strategy on behalf of a more auspicious life project and as a lifelong state and reject only the latter.

Beyond this framework, the WCY constantly negotiate between what is possible and what is probable (Appadurai, 2013: 29). They produce themselves as 'modern actors' (Meyer and Jepperson, 2000) by adopting transnational organizational standards, acting on principle-based 'new natural properties' (children's rights) and expanding the spheres of human agency (the future). However, they adapt these discourses according to their sociocultural and socioeconomic context and to their 'spaces of experience' and 'horizons of expectation' (Koselleck, 1995 [1979]). That way, they are doing future, because they not only actively shape their future but also follow action-centred, pragmatic approaches and stress the interconnectedness of the future with the present. 
This leads me to conceptualize the AMWCY's commitment towards the future as a commitment to its democratization. This 'democratization' transforms the future from a purely temporal concept into a materialized and political one and has a quantitative as well as a qualitative dimension. On the one hand, they promote their messages even in the most outback villages to reach as many people as possible. On the other hand, they appropriate and adopt powerful transnational tools, symbols and concepts and make the meaning of a 'good future' multivocal and polysemous (Appadurai, 2013). Their democratization of meaning, however, implies at the same time a dilution of the claim for nondiscrimination as contained in the 1989 UN Convention on the Rights of the Child (CRC): Instead of pressuring the state to entirely fulfil all requirements of Article 28 of the $\mathrm{CRC}$ in order to 'recognize the right of the child to education', the AMWCY holds the modest claim to 'learn to read and to write' and to 'be taught a trade'.

The most emancipatory in their approaches, it seems, is thus their emancipation from normative universal human rights claims as well as from any forms of exploitation. These are only at a first glance opposite to each other: the 'human rights culture' and the global capitalist system, intrinsically tied to experiences of inequality, are both rooted in the same cultural claims about values and rights originated in the global north (Butt, 2002: 3). The 'illusions of a global morality' (Butt, 2002: 3) are biased by Western individualism and assumptions about universal subjective (bodily) experiences (Butt, 2002: 12-13) and often lead to decontextualized and dehistoricized approaches to social problems, that are caused or aggravated by neoliberal economic policies (Butt, 2002: 9).

\section{Conclusion}

In this article, I have traced how the WCY re-interpret educational, social, moral, and economic resources in order to cope with their disadvantaged situation which threatens them with being excluded from 'having a future'. Their aim is to have control over their future and to have a (limited) choice about it. I have proposed to understand the commitment of the WCY towards their future as its democratization, because they multiply the meanings of a 'good future' as well as the number of minors having access to it. Importantly, by creating their own reference system for a 'good future' they do neither aim to provoke nor to form a protest movement, but want to reconcile different logics of thinking in order to initiate an 'endogenous change' in 'social harmony' (Enda Tiers-Monde Jeunesse Action, 2008: 72-73).

To prepare their future, the WCY make use of their agency at its best and negotiate new scopes for it, but also are aware of the limits they are restrained by. They mistrust any illusionary and risky endeavours, even, or maybe even more so, if they are inherent parts of (transnational or local) master narratives of success. Nevertheless, they need access to powerful, transnationally acknowledged resources in order to achieve their projects and therefore, for example, hold bank accounts or assist in French and new media classes.

In doing so, the WCY challenge the future as privilege of Senegal's socioeconomic elite and claim to be equally enabled to make careers, to develop their capacities and to upgrade their social positions. However, self-empowerment and disenchantment are closely linked in their project. The fact that they perceive their future as strongly dependent on their 
present, on the one hand, enables them to influence their future in the very now, and, on the other, precludes any too ambitious projects that they are unable to prepare.

\section{Declaration of Conflicting Interests}

The author(s) declared no potential conflicts of interest with respect to the research, authorship, and/or publication of this article.

\section{Funding}

The author(s) disclosed receipt of the following financial support for the research, authorship, and/ or publication of this article: The authors received financial support for the research of this article from the "Cultural Foundations of Integration" Center of Excellence, University of Konstanz, but no further financial support for the authorship and/or publication of this article.

\section{Notes}

1. This and all other participant names are pseudonyms.

2. Friendship is a social relationship, based on choice and voluntariness. Sharing and mutuality, even affection, seem to be universal principles of friendship, even though friendship can have various meanings in different societies, within one society and also among the persons defined as and defining themselves as 'friends' (Beer, 2001: 5805-5806).

3. Even though I agree with Ortner (1996: 12) who tries to dissolve a dichotomist perception of 'structure' and 'agency' and therefore reflects on 'structurally-embedded agency' and 'intentionfilled structure', I distinguish the two notions here, referring to the respective aspects of the sociocultural reality the WCY perceive to be possible and desirable to be changed by them or not.

4. As Wolof native speakers are not familiar with the phoneme 'sh' (and similar phonemes, codified in French with 'ch', 'g' or ' $j$ '), pronouncing (and writing) these as 's' is a typical mistake of Senegalese who have a rather low formal educational background and an only informal and oral contact with the French language.

\section{ORCID iD}

Sarah Fuchs (iD https://orcid.org/0000-0002-2064-7878

\section{References}

Agamben G (1998) Homo Sacer: Sovereign Power and Bare Life. Stanford, CA: Stanford University Press.

AMWCY (African Movement of Working Children and Youth) (2016) History. Available at: http://english.maejt.org/histoire/ (accessed 17 November 2016).

Appadurai A (2001) Deep democracy: Urban governmentality and the horizon of politics. Environment \& Urbanization 13(2): 23-43.

Appadurai A (2013) The Future as Cultural Fact: Essays on the Global Condition. London: Verso. Bada A, Coly H, d' Ovidio F, et al. (1999) Les 12 droits du Mouvement Africain des Enfants et Jeunes Travailleurs (MAEJT): fondement juridique, plate-forme revendicative ou instrument de développement. Dakar: ENDA Tiers-Monde Jeunesse Action.

Bayart J-F, Ellis S and Hibou B (1999) The Criminalization of the State in Africa. Oxford: James Currey.

Beer B (2001) Friendship, anthropology of. In: Smelser NJ and Baltes PB (eds) International Encyclopedia of the Social and Behavioral Sciences. Amsterdam: Elsevier, pp. 5805-5808. 
Benga NA (2001) Entre Jerusalem et Babylon: Jeunes et Espace publique à Dakar. Autrepart 18: $169-178$.

Bierschenk T, Chauveau J-P and de Sardan J-PO (2002) Local development brokers in Africa: The rise of a new social category. Working Paper no. 13. Mainz: Department of Anthropology and African Studies, Johannes Gutenberg-Universität Mainz, pp. 1-44.

Brettell C (2002) The individual/agent and culture/structure in the history of the social sciences. Social Science History 26(3): 429-445.

Butt L (2002) The suffering stranger: Medical anthropology and international morality. Medical Anthropology: Cross-Cultural Studies in Health and Illness 21(1): 1-24.

Conolly M and Ennew J (1996) Introduction: Children out of place. Childhood 3(2): 131-146.

Crivello G (2011) 'Becoming Somebody': Youth transitions through education and migration in Peru. Journal of Youth Studies 14(4): 395-411.

Diouf M (1996) Urban youth and Senegalese politics: Dakar 1988-1994. Public Culture 8(2): $42-66$.

Diouf M (2005) Wall paintings and the writing of history: Set/Setal in Dakar. GEFAME Journal of African Studies 2. Available at: http://hdl.handle.net/2027/spo.4761563.0002.102 (accessed 2 June 2014).

Enda Tiers-Monde Jeunesse Action (2000) Migrations, confiage et trafic d'enfants en Afrique de l'Ouest. Exode précoce des enfants en Afrique de l'Ouest. Dakar.

Enda Tiers-Monde Jeunesse Action (2003) Soutien aux talibés/garibous. Quelques actions d'amélioration du système éducatif des écoles coraniques au Sénégal, au Mali et au Burkina Faso. Dakar.

Enda Tiers-Monde Jeunesse Action (2008) Transformer les victimes en acteurs. Exode précoce des enfants en afrique de l'ouest. Dakar.

Enda, ILO, IOM, et al. (2011) Quelle protection pour les enfants concernés par la mobilité en Afrique de l'Ouest? Nos positions et recommandations. Projet «Mobilités»: Rapport régional de synthèse. Available at: https://www.unicef.org/wcaro/french/Rapport_FR-web.pdf (accessed 27 January 2019).

Ennew J (2000) The history of children's rights: Whose story? Cultural Survival Quarterly 24(2): 44-48.

Hahn K and Holzscheiter A (2013) The ambivalence of advocacy: Representation and contestation in global NGO advocacy for child workers and sex workers. Global Society 27(4): 497-520.

Hashim I and Thorsen D (2011) Child Migration in Africa. London: Zed Books.

ILO (1999) Convention 182 Concerning the Prohibition and Immediate Action for the Elimination of the Worst Forms of Child Labour. Available at: https://www.ilo.org/dyn/normlex/en/f?p=NORM LEXPUB:12100:0::NO::P12100_ILO_CODE:C182 (accessed 27 January 2019).

Jacquemin M (2006) Can the language of rights get hold of the complex realities of child domestic work? The case of young domestic workers in Abidjan, Ivory Coast. Childhood 13(3): 389-406.

Koselleck R (1995 [1979]) 'Erfahrungsraum' und 'Erwartungshorizont': zwei historische Kategorien. In: Koselleck R (ed.) Vergangene Zukunft: zur Semantik geschichtlicher Zeiten. Frankfurt: Suhrkamp, pp. 349-375.

Liebel M (2012) Do children have a right to work? Working children's movements in the struggle for social justice. In: Hanson K and Nieuwenhuys O (eds) Reconceptualizing Children's Rights in International Development: Living Rights, Social Justice, Translations. Cambridge: Cambridge University Press, pp. 225-249.

Loimeier R, Neubert D and Weißköppel C (2005) Einleitung: Globalisierung im lokalen Kontext - Perspektiven und Konzepte von Handeln in Afrika. In: Loimeier R, Neubert D and Weißköppel C (eds) Globalisierung im lokalen Kontext-Perspektiven und Konzepte von Handeln in Afrika. Münster: LIT Verlag, pp. 1-30. 
McCall L (2005) The complexity of intersectionality. Signs: Journal of Women in Culture and Society 30(3): 1772-1800.

Merry SE (2006a) Human Rights and Gender Violence: Translating International Law into Local Justice. Chicago, IL: University of Chicago Press.

Merry SE (2006b) Transnational human rights and local activism: Mapping the middle. American Anthropologist 108(1): 38-51.

Meyer JW and Jepperson RL (2000) The 'actors' of modern society: The cultural construction of social agency. Sociological Theory 18(1): 100-120.

Montgomery H (2008) Imposing rights? A case study of child prostitution in Thailand. In: Cowan JK, Dembour MB and Wilson RA (eds) Culture and Rights: Anthropological Perspectives. Cambridge: Cambridge University Press, pp. 80-101.

Morrow V (2010) Should the world really be free of 'child labour'? Some reflections. Childhood 17(4): 435-440.

Myers WE (1999) Considering child labour: Changing terms, issues and actors at the international level. Childhood 6(1): 13-26.

Nieuwenhuys O (1996) The paradox of child labor and anthropology. Annual Review of Anthropology 25: 237-251.

Nieuwenhuys O (2001) By the sweat of their brow? Street children, NGOs and children's rights in Addis Ababa. Africa 71(4): 539-557.

Nieuwenhuys O (2009) From child labour to working children's movements. In: Qvortrup J, Corsaro WA and Honig MS (eds) The Palgrave Handbook of Childhood Studies. Basingstoke: Palgrave Macmillan, pp. 289-300.

OAU (Organisation of African Unity) (1990) African Charter on the Rights and Welfare of the Child. Available at: http://www.achpr.org/instruments/child/ (accessed 27 January 2019).

Ortner S (1996) Making Gender: The Politics and Erotics of Culture. Boston, MA: Beacon Press.

Rossi B (2006) Aid policies and recipient strategies in Niger. In: Lewis D and Mosse D (eds) Brokers and Translators: The Ethnography of Aid and Development. Bloomfield: Kumarian, pp. 27-50.

Snow DA (2004) Framing processes, ideology, and discursive fields. In: Snow DA, Soule SA and Kriesi H (eds) The Blackwell Companion to Social Movements. Malden, MA: Blackwell, pp. $380-412$.

Thorsen D (2007) 'If only i get enough money for a bicycle!' A study of childhoods, migration and adolescent aspirations against a backdrop of exploitation and trafficking in Burkina Faso. Working Paper T21. Brighton: Development Research Centre on Migration, Globalisation and Poverty, University of Sussex.

United Nations (1989) Convention on the rights of the child. Available at: http://www.ohchr.org /en/professionalinterest/pages/crc.aspx (accessed 5 October 2013).

Van Daalen E and Mabillard N (2017) A tale of two conferences: Exploring the politics of global child labour policies. Available at: https://www.opendemocracy.net/beyondslavery/edward -van-daalen-nicolas-mabillard/tale-of-two-conferences-exploring-politics-of-glob (accessed 27 July 2018).

Van Gennep A (2000 [1909]) Les rites de passages. Paris: A. et J. Picard.

Vigh HE (2009) Motion squared: A second look at the concept of social navigation. Anthropological Theory 9(4): 419-438.

Waage T (2006) Coping with unpredictability: 'Preparing for life' in Ngaoundéré, Cameroon. In: Christiansen C, Utas M and Vigh HE (eds) Navigating Youth, Generating Adulthood. Social Becoming in an African Context. Uppsala: Nordiska Afrikainstitutet, pp. 61-87.

Woodhead M (1998) Children's perspectives on their working lives: A participatory study in Bangladesh, Ethiopia, The Philippines, Guatemala, El Salvador and Nicaragua. Radda Barnen, Stockholm, Sweden. Available at: http://oro.open.ac.uk/28493/ (accessed 2 August 2017). 